Review Article

\title{
Beliefs and Folk Beliefs of Vietnamese People
}

\author{
Trinh Thi Thanh* \\ University of Transport and Communications, Vietnam \\ *Corresponding Author \\ Trinh Thi Thanh
}

\section{Article History}

Received: 05.08.2020

Accepted: 12.08 .2020

Published: 16.08 .2020

\begin{abstract}
Belief plays an important role in the spiritual life of Vietnamese people. This research indicates that there are many folk beliefs in Vietnam. These are beliefs created by people in their own lives. Through the process of existence and development, these beliefs have become an integral part of the spiritual life of Vietnamese people. Based on the analysis and evaluation of belief activities, the study shows the values that these beliefs bring to human life.
\end{abstract}

Keywords: Belief, folk belief, spiritual life, Vietnamese people.

\section{INTRODUCTION}

The mighty and thriving of many people, of any country in any geographical situation always raises great questions. Because the history of mankind has ever witnessed, many prosperous nations, after a long time the brilliant appearance has gradually faded, even permanently disappeared. Can say about the once-illustrious nations in the south of Dai Viet such as the Chiem Thanh Kingdom or the Funan Kingdom are a testament. In them, there used to be civilized institutions, each with unique peak cultural values, but withered, even fewer traces until this day like the Funan Kingdom [1].

There have been many profound theories about the survival of a nation, a people from a cultural perspective. In addition to countless different rational causes, the overall achievement is that the survival of a country always depends on two big factors [2]. First, there must be a profound inner force of its own cultural quintessence, and that elite is especially shown in man. The other is to always ensure a genuine civilization, equally high as the surrounding civilizations. Happiness for Vietnam, we have owned both of these things for thousands of years [3]. The problem of elite people is too obvious, because as "Dai Cao Binh Ngo" of Nguyen Trai confidently wrote: "Although the strengths and weaknesses are different, Heroes are always present also". As for the greatness of civilized culture, just feeling through the forms of religious beliefs imbued with Vietnamese identity is evident [1]

Since ancient times, with abundant natural conditions, the Vietnamese live mainly on natural exploitation. Therefore, worship of nature soon became a long and important practice in religious beliefs life [4]. Moreover, Vietnam is a crossroads of many ethnic groups and streams of civilization. Each religion, when introduced into Vietnam, has been transformed, becoming closer to indigenous customs and ideas [4, 5].

Vietnam is a country with many beliefs and religions, including beliefs and religions imported from abroad, but there were also beliefs that appear in Vietnam itself. We can refer to typical folk beliefs such as the worship of ancestors' belief, the worship of Mother Goddesses belief, the worship "Thành Hoàng làng” belief (the Village's Tutelary god belief), worship of the souls and many other typical folk beliefs [6, 7].

Traditional beliefs have appeared since the beginning of Vietnamese history [8]. With the importance of the wet rice industry, farming, animal husbandry, Vietnamese ethnic groups worship the symbol of yin and yang, the harmony between heaven and earth, and the proliferation of all things. Traditional beliefs (traditional means many, real means flourishing) are found in folk paintings such as Dong Ho paintings (Bac Ninh province today) with pictures of buffaloes,

Copyright @ 2020: This is an open-access article distributed under the terms of the Creative Commons Attribution license which permits unrestricted use, distribution, and reproduction in any medium for non commercial use (NonCommercial, or CC-BY-NC) provided the original author and source are credited. 
pigs, chickens, fishes, mice, cats, trees; or in old cultural products such as the image of mating men and women engraved on the bronze drum found in Dao Thinh village (Yen Bai province today), dating back to 500 BC. The customs of "pounding the mortar to welcome the bride" is also this an expression of the traditional belief, the pestle and the mortar are the symbols for male and female genitalia [2].

For most the Vietnamese, the family is the best, so the ancestor worship can be considered almost "national religion". Regardless of whether the family is rich or poor, every family respectfully preserves an altar of ancestors. On the anniversary of the Lunar New Year, children and grandchildren sincerely make an offering tray or worship, or salty respectfully present to the altar, hoping that grandparents and ancestors will gather to protect the offspring who are struggling hard to make a living [6]. All suddenly forgot the phobia of fame and kneel before the altar of the ancestors. Everyone has a glittering face of true repentance, from that the people will all be sublimated to become benevolent and gentle [7].

Natural cult worship: The nature of Vietnamese people is mother, the image of the universal goddess that brings prosperity, completeness, and protection for each their child [4]. This is evident in the cult of the Mother Goddess, formed by the influence of Chinese Taoism, combined with the practices of the Goddess period from prehistoric times. The image of Vietnamese women is worshiped, which is quite special when placed in the context of the country subjected to many Confucian teachings and rituals.

One of the most popular beliefs of the Vietnamese nation in all parts of the country from North to South is the belief of worshiping the Village's Tutelary gods in the villages [5,8]. The Village's Tutelary god is worshiped in village communal houses and is highly revered by the villagers. In the national belief system of Vietnam, the belief of worshiping the Village's Tutelary god has become an indispensable part of the spiritual life of Vietnamese people [9]. The belief of worshiping the Village's Tutelary was born from the tradition of "drinking water, remember the source" of our people with gratitude, promoting the role of people with meritorious services to the people and the country [10].

Faith in the dead and in the next generation depends largely on a person's religion and culture, on a community of people. For many Vietnamese, this belief goes from the belief that the soul only reaches its ultimate goal after many reincarnations, to the idea that life will now determine its final destiny [3]. Consequently, one person can feel confident that he will eventually merge with the ultimate reality after death, others will surely reach Nirvana, and others will believe that he will be rewarded in heaven. So what is the truth? Because our beliefs affect our attitude, actions, and decisions, are we not interested in finding answers to that question? The dead are not finished but their souls still exist. Depending on the behavior of those who live with those who have died, they (those who are still alive) may be blessed by the soul or punished by the soul, encountering unfortunate things in life [5].

There are many other folk beliefs of Vietnam that the authors have not had the opportunity to study and present here. Within the limited scope of the book, with limited research capacity, the authors focused on understanding the concepts of beliefs, folk beliefs, beliefs classification, and four typical Vietnamese folk beliefs.

\section{Beliefs ANd Folk BeliefS Beliefs}

According to the Han-Vietnamese Dictionary of scholar Dao Duy Anh [1], belief is explained: "Superstition admiration for a religion or a doctrine". Similarly, in the Vietnamese Dictionary by Van Tan (editor), belief means: "Belief in a religion: Freedom of belief" [1]. Thus, in the etymological of sense, religion is the religious belief in every human being.

\section{Beliefs from the perspective of Religious Studies, Anthropology}

This group of views said that beliefs are the psychological state of people towards the sacred forces, which are part of religion and cannot be separated from religion, which is the basis for forming religion. In Vietnam, a representative representative of this group of views is Dang Nghiem Van. In his work on Theory of religion and the situation of religion in Vietnam [10,11], he analyzed quite clearly the concept of belief as a religious faith, beliefs are not completely separated from religion: "If you understand beliefs are beliefs that have a part outside of religion, if understood as religious beliefs (belief, believe, in a narrow sense, croyance religieuse), beliefs are only a major part of the religion" $[12,13]$. The author also expressed his disagreement and suggested revisiting when considering religion and belief as two low and high levels are different. Because of the religious researcher had accepted that the decisive factor of religion was virtue faith or belief, it is the only measure of the inferiority of the religions in the community, and of believers with their religion. If cultural equality (including religion) is accepted, there is no appreciation of one religion over another [11]. 
In particular, when referring to a concept used by many people as folk beliefs, he thought that this is a popular religion: "The term may be a way of understanding religion in the popular way, meaning customary, public opinion or engaging in rituals, not in the mainstream that comes primarily from, the study of doctrine, reflection and enlightenment. Or it can also be understood that the forms of national religion have been handed down from ancient times, close to the community such as festivals, pilgrimages, holidays with parades, dancing, even the divination form, general number, etc. There was the intellectual class, though few believed but still participated. At festivals, processions, etc., it is still responded by the majority of the popular class in rural areas, according to a tradition that has long existed in the nation" [14].

\section{Beliefs from a cultural perspective}

In a work about religion in Vietnam, Le Nhu Hoa said that, in essence, beliefs, as well as religions, are a method of realizing and improving reality. The similarity between them and the improvement of reality. The differences between them are just historical features $[14,15]$. There are 5 criteria for distinguishing beliefs and religions, namely: The source (beliefs only consist of spiritism, while religion in addition to spiritism also has totem or other supernatural theory); objects of worship (beliefs: All things spiritual, polytheistic, religious: Unity, only one god); methods of practice (beliefs: Magic, religion: Religious rituals); institutions (beliefs are not yet complete, religion is complete about material institutions, clergy, formal system, canon law, complete canonical, systematic scriptures, ethical beliefs, have community sentiment about belief); sphere of influence, social context (beliefs: Narrow, usually ethnic communities, in non-state societies; Religion: Wide, popular among ethnic, national, ethnic communities gender, in societies with a state) [14, 16].

The above assessment shows that both beliefs and religions are human creations. In the process of existence and development, people created beliefs and religions to make spiritual support for themself and the community. Over time, such creativity has become a traditional system of values, lifestyles on which people show their faith and values [17].

\section{Folk Beliefs}

Vietnamese folk beliefs, also known as Vietnamese traditional beliefs, are indigenous beliefs of ethnic groups living on the Vietnamese territory through many generations $[12,18]$.

Vietnamese folk beliefs believe that anything has a soul, so the ancient people worshiped a lot of gods, especially those related to agriculture such as heaven, moon, earth, forest, river, mountain, etc to be blessed. For ethnic minorities, each ethnic group has its own belief form. However, the most typical feature is that the original forms of beliefs and folk beliefs are still preserved among ethnic groups such as the Tay-Thai and Hmong-Dao groups; Hoa-San Diu-Ngai group; Cham-Ede-Gia Rai group; Mon-Khmer group [14].

Besides, one of the most common customs and practices of the Vietnamese and some other ethnic minorities is the ancestor worship and death anniversary of the deceased. In Vietnamese families, every family has an ancestor altar and commemoration, remembering the merits of the ancestors is very important. Besides ancestor worship in each family and clan, many villages in Vietnam have a communal house of worshiping tutelary gods. The custom of worshiping tutelary gods in village temples (Village's Tutelary god) is a unique feature of Vietnamese villages. The tutelary god worshiped in communal houses can be gods or outstanding figures with great merits such as the ancestors of a trade village or a national hero who had "founding the nation", opposing invaders [19].

For several centuries in Vietnam, Mother Goddess worship has been a source of strength, inspiration, and spirituality, particularly among working-class families. Along with the worship of ancestors, the belief of worshiping the Village tutelary gods, the worship of Mother Goddess has kept an important position in the spiritual life of the Vietnamese people $[12,18]$.

For many Vietnamese, they believe in the existence of a soul. This belief goes from the belief that the soul only reaches its ultimate goal after many reincarnations, to the idea that life will now determine its final destiny [14]. Consequently, one person can feel confident that he will eventually merge with the ultimate reality after death, others will surely reach Nirvana, and others will believe that he will be rewarded in heaven. From the faith and the punishment or the blessing of the soul has led to the worship of the souls of Vietnamese People [19].

Also, Vietnamese people also worship gods such as the kitchen god, the earth god, the river god, the mountain god, etc. All that worship has formed a system of Vietnamese folk beliefs extremely rich and diverse as we see it today [19]. 


\section{CONCLUSION}

The people's right to freedom of belief and religion is specified in many legal documents of the Vietnamese state. In Vietnam, 95\% of the population has a religious and belief life. Every year, around 8,500 national and local religious festivals or beliefs are held.

Religious believers are free to perform religious belive, to express and practice their religious faith. Religious dignitaries and priests are free to practice religious activities according to canon law.

The ordination, appointment, and transfer of dignitaries are done in accordance with church regulations. Religious organizations that have been recognized as a legal entity over the years have experienced an increase in the number of church, pagoda facilities, believers, religious dignitaries, on new construction or restoration of institutions, worship facilities, the guarantee of scriptures, religious activities according to the charter, rules, and doctrines, canon law. Dignitaries and monks are allowed to study and train in the country and abroad or to participate in religious activities abroad. Many foreign religious organizations have come to exchange with Vietnamese religious organizations.

Religious and belief life is an inseparable part of people's spiritual life. Vietnam's development history for thousands of years has proved the richness and diversity of beliefs and religions.

\section{REFERENCE}

1. Anh, D. D. (1998). Sino-Vietnamese dictionary. Dong Thap: Đong Thap Universal.

2. Van, V. H., Long, N. T., Thanh, T. T., Dong, T. K., \& Luong, P. V., (2020). Folk Beliefs of Vietnamese People. India - United Kingdom: Book Publisher International. DOI: 10.9734/bpi/mono/978-93-89816-92-1

3. Van, V. H. (2019). Comparative Buddhism in India, China, Vietnam and the spirit of localization in Vietnamese Buddhism. International Journal of Recent Scientific Research. 10(6):1-7.

4. Luong, P. V., \& Van, V. H. (2019). Study of the Laws under the Feudal Dynasties of Vietnam. Addaiyan Journal of Arts, Humanities and Social Sciences, 1(7).

5. Van, V. H. (2019). Beliefs Worship the Village's Tutelaray God in the Beliefs Life of Vietnamese People. Humanities and Social Sciences. 7(5):156-164.

6. Van, V. H., \& Long, N. T. (2019). Identify the Values of Ancestor Worship Belief in the Spiritual Life of Vietnamese People. International Journal of Philosophy. 7(4):60-66.

7. Van, V. H. (2019). The Worship belief of the Mother Goddess in the spiritual life of Vietnamese people. Hanoi: People's police. ISBN: 987-604-72-3647-3.

8. Van, V. H. (2020). Origin of Worshiping the Mother Goddress in Vietnam. Asian Research Journal of Arts \& Social Sciences. 10(2):10-29.

9. Van, V. H. (2020). Redefining the Position of Daoism (Taoism) in Vietnamese History from the 2nd Century to the 9th Century. Research Journal of Arts \& Social Sciences. 10(3):54-60.

10. Van, V. H. (2020). From the Belief of the Immortality of the Soul, the Blessing or the Harassing of the Soul towards People to the Worship of the Souls of Vietnamese People. Asian Social Science. 16(3):1-11.

11. Van, V. H. (2020). Confucianism during the Feudal Dynasties and Culture of Vietnam. Publisher: LAP LAMBERT Academic Publishing. ISBN: 978-620-2-52562-6.

12. Hang, L. T., \& Van, V. H. (2020). Method of Printing Carved on Wood under the Nguyen Dynasty of Vietnam: Study of Woodblocks Recognized by UNESCO as a World Documentary Heritage. International Journal of Psychosocial Rehabilitation. 24(10):2701-2708.

13. Van, V. H. (2020). Religious trends before the impact of globalization and Vietnam's religious policy.

14. Trung, N. S., \& Van, V. H. (2020). Educating Traditional Cultural Values in Vietnam Universities. South Asian Research Journal of Humanities and Social Sciences. 2(3):210-214.

15. Van, V. H. (2020). The Buddhism cultural heritage in the cultural life of Vietnamese people. Humanities \& Social Sciences Reviews. 8(3):811-823.

16. Trung, N. S., \& Van, V. H. (2020). Vietnamese Cultural Identity in the Process of International Integration. Journal of Advances in Education and Philosophy. 4(6):220-225.

17. Hoang, P. D., Phong, N. X., \& Van, V. H. (2020). The Influence of Confucianism in the Law Code of the Nguyen Dynasty of Vietnam. Journal of Advances in Education and Philosophy. 4(6):201-207.

18. Van, V. H. (2020). The Imprint of Buddhism in Pagoda Architecture under the Ly Dynasty and Historical Values. International Journal of Psychosocial Rehabilitation. 24(6).

19. Van, V. H., (2017). Taoism and expressions in Vietnamese folk beliefs. Hanoi: National Politics the Truth. ISBN: $978-604-57-2610-5$. 